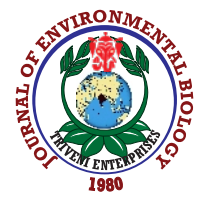

\title{
Determination of compositional differences of lichens on Pinus brutia in different environmental conditions
}

\section{Tufan-Cetin}

Program of Environmental Protection and Control, Department of Environmental Protection Technology, Vocational School of Technical Sciences, Akdeniz University, Antalya-07058, Turkey

*Corresponding Author Email : ozgetufan@akdeniz.edu.tr

\begin{abstract}
Aim: Epiphytic lichens are biological indicators, which can give information about the environmental changes of the ecosystem. The differences in richness and community compositions of lichens can indicate the environmental quality of their location. This study was done in order to examine the possible differences in richness and in community composition of lichens that may have occurred in the research area, Kurşunlu Waterfall Nature Park and surroundings.

Methodology: Kurşunlu Waterfall Nature Park and surroundings was divided into 4 sections; natural area near brook, natural pine forest area, planted pine forest area and agricultural greenhouses area. The study was planned to focus on epiphytic lichens living on Pinus brutia Ten. trees. European Guideline, which is a standardized method to assess lichen diversity (LDV) on tree bark for monitoring environmental stress, was used for monitoring quality of four different environmental conditions with lichens. In order to determine the differences of lichen community composition of these four conditions, some statistical analyses were performed.

Results: Lichen richness of planted pine forest area was found poorer and statistically different than the other areas. In addition, the lichen community composition of natural pine forest area was found significantly different than the agricultural greenhouse area and the natural area near brook, partly different than the planted pine forest area. Statistical evaluations indicate that the natural pine forest area had natural or semi-natural habitat characteristics and there was no or less eutrophication in this region. Also it showed that other areas were affected by the presence of human damage and eutrophic pollution load in the environment. This eutrophic pollution load was related to non-ecological agriculture applications around the park.

Interpretation: This study proves that epiphytic lichens change their community composition by adapting to changes in environmental conditions. Also this study showed that lichens are strong indicators of environmental quality.

Key words: Antalya, Diversity, Lichenized Fungi, Lichens, Pinus brutia, Turkey

Four environmental conditions were selected from the research area (Kursunlu Waterfall Nature Park and surroundings - Antalya - Turkey

1. Natural area near brook (NNB)

2. Natural pine forest area (NPF)

3. Planted pine forest area (PPF)

4. Agricultural greenhouses area (AG)

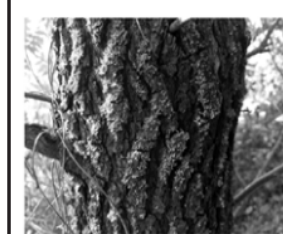

Sampling and Data Recording

Epiphytic lichen species were collected according to the European Guideline from Pinus brutia which is the dominant tree species of the Park. The quantitative description of species composition in each survey sites were calculated with frequency data of epiphytic lichens

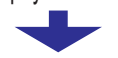

Groups Tools Window Options

Cluster Analysis Two-way Cluster Analysis MRPP

Blocked MRPP (MRBP) TWINSPAN

Indicator Species Analysis

Mantel Test

PerMANOVA

Data Analysis (NMS, MRPP, ISA)

The lichen richness of the PPF was found to be poorer and statistically different than the other areas.

The lichen community composition of the NPF was found to be significantly different than AG and NNB, partly different than PPF. NPF has natural or semi-natural habitat characteristics and their is no or less eutrophication in this region.
\end{abstract}

How to cite : Tufan-Cetin, O.: Determination of compositional differences of lichens on Pinus brutia in different environmental conditions. J. Environ. Biol., 41, 735-744 (2020). 


\section{Introduction}

Lichens are affected by abiotic factors such as high temperatures, humidity, climate changes and wind direction. Due to rapid destruction of natural areas, increase in human population, urban growth and pollution pose threat to survival of lichens (Käffer et al., 2011; Pinho et al., 2012). Such changes in environmental conditions can lead to disappearance or proliferation of lichens. For example, agricultural land use affects the number of lichen species (Bergamini et al., 2005; ZarabskaBożejewicz and Kujawa, 2018). Therefore, lichens are biological indicators that can give information about positive or negative changes in the environmental conditions of an ecosystem (Smith et al., 1993; McCune, 2000; Seaward, 2004; Jovan, 2008; Nash, 2008; Will-Wolf et al., 2015). It has been confirmed that species richness (Llop et al., 2012), abundance (Johansson and Ehrlén, 2003), frequency (Gombert et al., 2003), cover (Will-Wolf et al., 2015) or indices created by combinations of these quantitative data (Pinokiyo et al., 2008; Llop et al., 2012) of epiphytic lichens can be used for determination of environmental quality of the areas (Hawksworth and Rose 1970; Asta et al., 2002; Nimis et al., 2002; Paoli et al., 2015).

Nimis and Martellos (2017) classified lichens according to several characteristic properties such as from acidophilic to basophilic, hygrophytic to xerophytic, eutrophication sensitive to resistant and UV tolerant to shade-loving. Thus, the preference of environmental conditions of each lichen species are known. Moreover; the density of only one ecological group of lichens can give information about the ecological quality of the environment. For example, in a study it was determined that the richness of lichens such as oligotrophic, hygrophytic and acidophilic is reduced due to traffic pollution (Llop et al., 2012). On the other hand, cover and frequency of nitrophytic lichens increase due to exposure to different forms of nitrogen, which are significant environmental pollutants (Frati et al., 2007; Pinho et al., 2011; Jovan et al., 2012). But in natural ecosystems where the lichen variety is high, it is difficult to determine the cause of environmental change using lichens (Giordani, 2006; Cristofolini et al., 2008). Therefore, this study was planned to focus only on epiphytic lichens living on a single tree species.

Kurşunlu Waterfall is one of the rare protected areas in the urban area of Antalya Province. It was a recreation area 1979 to 1991. After 1991, it was given the status of National Park due to rich biodiversity. In 1985, traditional agriculture methods had been rapidly left in Antalya and the surroundings of the park began to be covered with greenhouses. Today, the park is completely surrounded by open system greenhouses leading to discharge of fertilizers and pesticides directly into the soil and water resources.

Kurşunlu Waterfall Nature Park (KWNP) has a brook flowing through the region that is covered by both natural and planted trees of Pinus brutia Ten. and surrounded by agricultural greenhouses. There are also pine trees inside greenhouse areas. In order to investigate the difference in species richness and community composition of lichens that may have occurred under these environmental conditions, four areas were selected and named as natural area near brook, natural pine forest area, planted pine forest area and agricultural greenhouses area. Keeping in view of the above, the aim of this study was investigate species richness and community composition of lichens on pine trees, and to reveal the relationship between determined environmental quality indicator taxa and general species composition in the study sites.

\section{Materials and Methods}

Study area and survey sites: KWNP is located in Antalya, south-west cost of Turkey (Fig. 1). The research was carried out on 660 ha area in and around the park. Altitudes of the area are between 70 and $110 \mathrm{~m}$ above sea level. Lichen samples were collected between $36^{\circ} 59.24^{\prime}-37^{\circ} 02.25^{\prime} \mathrm{N}$ and $30^{\circ} 48.38^{\prime}-30^{\circ}$ $51.06^{\prime} \mathrm{E}$ coordinates. A brook, one of the tributaries of the Aksu River, runs through the park. Pine and other natural trees surround this brook. The park also has a pine forest consisting of two parts: natural and planted. Afforestation began in 1976 after a fire broke out in 1970 (Sarıbaşak et al., 2007). The outside of the park, which was previously a part of the pine forest, is now covered with greenhouses. There are still pine trees in this area. In this study, the park was divided into four different parts: Natural area near brook (NNB), Natural pine forest area (NPF), Planted pine forest area (PPF), Agricultural greenhouses area (AG). For all four environmental parts, thirteen survey sites were divided into approximately $350 \times 350 \mathrm{~m}$ squares and totally in 52 squares (Fig. 1). As shown in Fig. 1, letters from north to south and numbers from west to east were used to name the survey sites.

Sampling: Epiphytic lichen species were collected according to the European Guideline from P. brutia, which is the dominant tree species of the Park. European Guideline, based on German VDI and Italian Guideline of ANPA (Asta et al., 2002a, b) is a standardized method to assess lichen diversity (LDV) on tree bark for monitoring environmental stress. To implement the method, four different trees were selected at each survey site. Quadrats $(50 \times 10 \mathrm{~cm})$ with five $(10 \times 10 \mathrm{~cm})$ squares were attached to four sides (North, South, West, East) of tree stands, one meter above the ground. The frequency of each specie in each quadrat squares were noted (Table 1). The total means of frequencies of all lichen taxa in each survey area constitutes the quantitative description of species composition of that survey area. All the field work was carried between $3^{\text {td }}$ to $5^{\text {th }}$ October, 2015. Collected samples from research area were deposited in the private fungarium in University of Akdeniz.

Identification of samples: Lichen samples were dried under room conditions. Morphological and anatomical investigations 


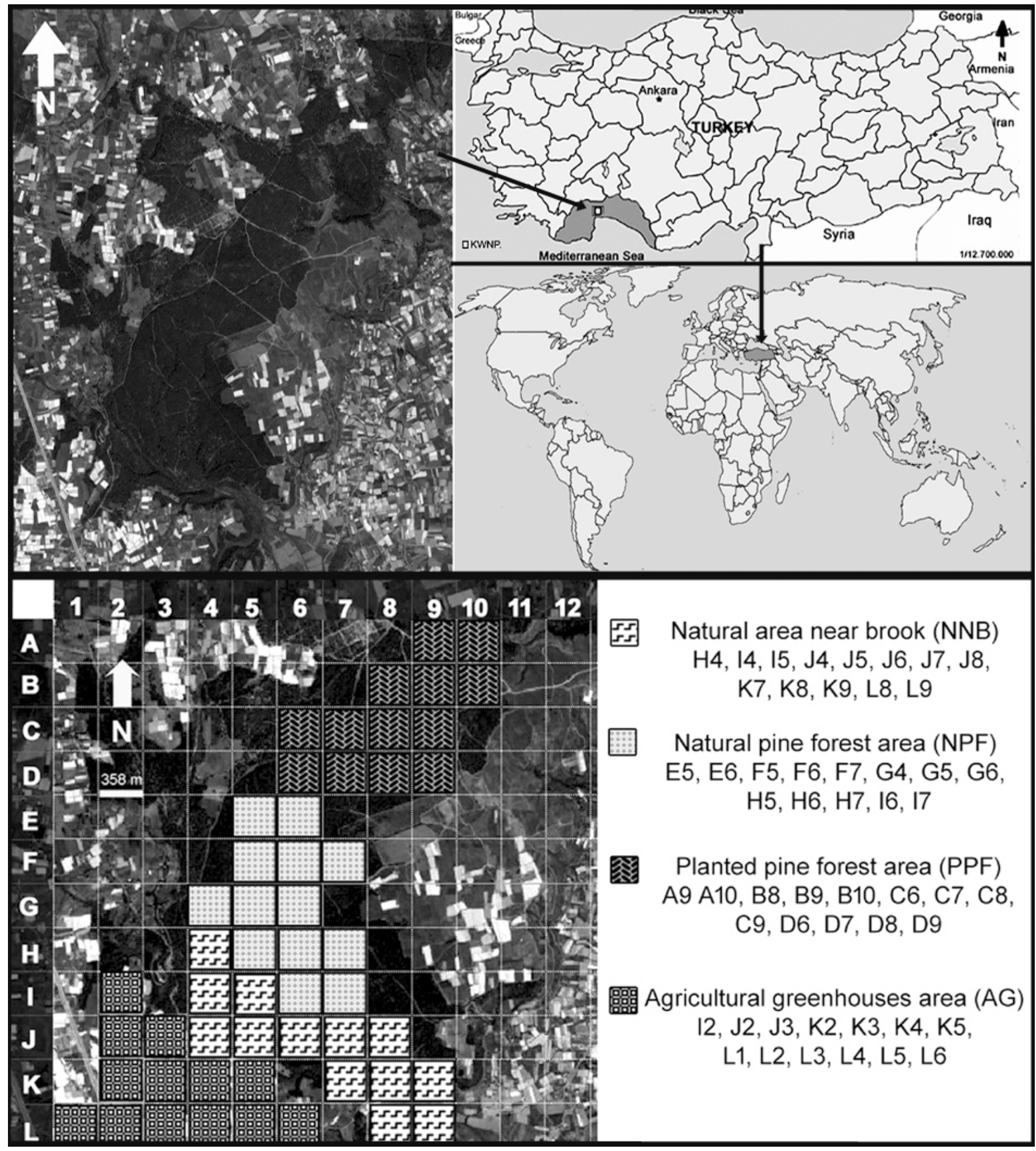

Fig. 1 : Location of research area in Turkey and in the world and map of four selected environmental conditions with thirteen repetitive survey sites in the research area (The research area map was created on the base layer taken from the Google Earth Pro 7.1.2.2041).

were carried out with a compound microscope (Nikon Eclipse E100) and a stereoscopic zoom microscope (Nikon SMZ 745T). Identification of lichen samples was done following the protocole of Wirth (1995), Giralt (2001), Smith et al. (2009), McCune (2006) etc. Spot test was used following the standard procedure.
Data analysis: Firstly, the normality of species richness data was examined by Shapiro-Wilk test. As species richness were not normally distributed $(p=0.000)$, the Kruskal Wallis H test (Kruskal and Wallis, 1952) was used to determine difference within the richness data obtained from each survey site. Since variances 
Table 1 : Species richness and percentage data of frequency of all lichen taxa at each sites

\begin{tabular}{|c|c|c|c|c|c|c|c|c|c|c|c|c|c|c|c|c|c|}
\hline & \multicolumn{17}{|c|}{ Species } \\
\hline & $\begin{array}{l}\text { A. } \\
\text { punc. }\end{array}$ & $\begin{array}{l}\text { A. } \\
\text { pyra. }\end{array}$ & $\begin{array}{l}\text { C. } \\
\text { furf. }\end{array}$ & $\begin{array}{l}\text { E. } \\
\text { prun. }\end{array}$ & $\begin{array}{l}H . \\
\text { poll. }\end{array}$ & $\begin{array}{l}H . \\
\text { scal. }\end{array}$ & $\begin{array}{l}\text { L. } \\
\text { chlar. }\end{array}$ & $\begin{array}{l}\text { L. } \\
\text { expa. }\end{array}$ & $\begin{array}{l}L . \\
\text { elae. }\end{array}$ & $\begin{array}{l}L . \\
\text { albe. }\end{array}$ & $\begin{array}{l}P . \\
\text { tili. }\end{array}$ & $\begin{array}{l}P . \\
\text { orbi. }\end{array}$ & $\begin{array}{l}P . \\
\text { adsc. }\end{array}$ & $\begin{array}{l}R . \\
\text { anom. }\end{array}$ & $\begin{array}{l}R . \\
\text { dalm. }\end{array}$ & $\begin{array}{l}\text { V. } \\
\text { hemi. }\end{array}$ & $\begin{array}{l}X . \\
\text { pari. }\end{array}$ \\
\hline \multicolumn{18}{|c|}{ Natural Area Near Brook (NNB) } \\
\hline $\mathrm{H} 4$ & 1.25 & & & & & & & & 3.75 & 1.25 & & & & & & & 1.25 \\
\hline 14 & & & & & & & & & 1.25 & & & & & & & & 15.00 \\
\hline 15 & 2.50 & 1.25 & & & & & & & 6.25 & 1.25 & & 3.75 & & & & & 1.25 \\
\hline J4 & & & & & & 3.75 & & & & & & & 8.75 & & & & 7.50 \\
\hline J5 & 1.25 & & & & & & 2.50 & & 5.00 & 1.25 & & & 1.25 & & & & 2.50 \\
\hline J6 & & 1.25 & & & & & & & & & & 1.25 & & & & & 1 \\
\hline J7 & & & & & & & & & & & & & & & & & 11.25 \\
\hline J8 & & 1.25 & & & & & 1.25 & & 2.50 & & & 2.50 & 3.75 & & & & 1.25 \\
\hline K7 & 2.50 & & & & & 2.50 & 5.00 & & & & & & 5.00 & & & & 2.50 \\
\hline K8 & 1.25 & & & & & & & & & & & 1.25 & 5.00 & & & & \\
\hline K9 & 1.25 & & & & & & & & & & & 2.50 & & & & & 6.25 \\
\hline L8 & 1.25 & & & & & 1.25 & 2.50 & & & & & & & & & & 3.75 \\
\hline L9 & 5.00 & & & & & & & & & & & & & & & & 12.50 \\
\hline Rich & + & + & & & & + & + & & + & + & & + & + & & & & + \\
\hline \multicolumn{18}{|c|}{ Natural Pine ForestArea (NPF) } \\
\hline E5 & & & 1.25 & & & & & & & & & & 1.25 & & & & \\
\hline E6 & & 2.50 & 1.25 & & & & & & & 1.25 & & & & & & & 1.25 \\
\hline $\mathrm{F} 5$ & & & & 2.50 & & & & 2.50 & 1.25 & & 3.75 & & 2.50 & & & & 2.50 \\
\hline F6 & & & & & & & & 1.25 & 2.50 & 5.00 & & & & & & & \\
\hline $\mathrm{F} 7$ & & 2.50 & & & & & & & & & & & & & & 1.25 & \\
\hline G4 & & 2.50 & 1.25 & & & & & & & & & & & & 1.25 & 1.25 & \\
\hline G5 & & & & 1.25 & 1.25 & & & 2.50 & 1.25 & 2.50 & 2.50 & & 1.25 & 1.25 & 1.25 & & 1.25 \\
\hline G6 & & 1.25 & 2.50 & & & & & & 1.25 & & & & & & & & \\
\hline $\mathrm{H} 5$ & & 3.75 & & & & & & & & 2.50 & 1.25 & & & & & & \\
\hline $\mathrm{H} 6$ & & 1.25 & 1.25 & 1.25 & & & & & & 3.75 & 1.25 & & & & & & \\
\hline $\mathrm{H} 7$ & & 1.25 & 1.25 & & 2.50 & & & & & & & & & & & & \\
\hline 16 & & & 1.25 & & & & & 3.75 & & & & & & & & 2.50 & 1.25 \\
\hline 17 & & & & & 1.25 & & & & & & & & 1.25 & & & & \\
\hline Rich & & + & + & + & + & & & + & + & + & + & & + & + & + & + & + \\
\hline \multicolumn{18}{|c|}{ Planted Pine ForestArea (PPF) } \\
\hline A9 & & & & & & & & & & & & & & & & & 1.25 \\
\hline $\mathrm{A} 10$ & & & & & & & & & & & & & & & & & 1.25 \\
\hline B8 & & & & & & & & & 2.50 & & & & 3.75 & & & & \\
\hline B9 & & & & & & & & & 1.25 & & & & & & & & 1.25 \\
\hline B10 & & & & & & & & & & & & & 1.25 & & & & \\
\hline $\mathrm{C} 6$ & & & & & & & & & 1.25 & & & & & & & & 2.50 \\
\hline $\mathrm{C} 7$ & & & & & & & 2.50 & & & & & & & & & & \\
\hline $\mathrm{C} 8$ & & & & & & & 1.25 & & & & & & & & & & \\
\hline $\mathrm{Cg}$ & & & & & & & & & 2.50 & & 1.25 & & & & & & 2.50 \\
\hline D6 & & & & & & & & & 1.25 & & & & & & & & \\
\hline D7 & & & & & & & & & & & & & & & & & 3.75 \\
\hline D8 & & & & & & & & & 1.25 & & & & & & & & \\
\hline D9 & & & & & & & & & & & & & 2.50 & & & & \\
\hline Rich & & & & & & & + & & + & & + & & + & & & & + \\
\hline \multicolumn{18}{|c|}{ Agricultural Greenhouses Area (AG) } \\
\hline 12 & & 1.25 & & & & & & & 2.50 & 1.25 & & & 1 & & & & \\
\hline $\mathrm{J} 2$ & & & 2.50 & & & & & & & & & 6.25 & 1.25 & & & & \\
\hline $\mathrm{J} 3$ & 2.50 & & & & & & 1.25 & & 1.25 & & & 2.50 & & & & & \\
\hline $\mathrm{K} 2$ & & & & & & & 3.75 & & & & & & & & & & 1.25 \\
\hline K3 & & & 1.25 & & & & & & & & & 5.00 & 5.00 & & & & 7.50 \\
\hline
\end{tabular}




\begin{tabular}{|c|c|c|c|c|c|c|c|}
\hline K4 & 1.25 & & & & 1.25 & & 2.50 \\
\hline K5 & & 1.25 & & & & 1.25 & 21.25 \\
\hline L1 & 1.25 & 1.25 & 1.25 & & 2.50 & 2.50 & 1.25 \\
\hline L2 & 1.25 & 1.25 & & & 3.75 & 6.25 & 1 \\
\hline L3 & & & & & & & 6.25 \\
\hline L4 & 2.50 & 1.25 & 1.25 & 2.50 & 2.50 & 1.25 & 2.50 \\
\hline L5 & & & & & 5.00 & 7.50 & 3.75 \\
\hline L6 & 1.25 & & & & 2.50 & & 8.75 \\
\hline Rich & + & + & + & + & + & + & + \\
\hline
\end{tabular}

General abbreviations: Rich.: Species richness; +: availability Locality abbreviations: AG: Agricultural Greenhouses Area; NNB: Natural Area Near Brook; NPF: Natural Pine Forest Area; PPF: Planted Pine Forest Area; A9, A10...L9: Divided survey sites of four environmental conditions (Fig 1.b). Species abbreviations: A. punc.: Amandinea punctata; A. pyra.: Athallia pyracea; C. furf.: Collema furfuraceum; E. prun.: Evernia prunastri; H. poll.: Huneckia pollinii; H. scal.: Hypocenomyce scalaris; L. chlar: Lecanora chlarotera; L. expa.: Lecanora expallens; L. elae.: Lecidella elaeochroma; $L$. albe.: Lepra albescens; P. tili.: Parmelina tiliacea; P. orbi.: Phaeophyscia orbicularis; P. adsc.: Physcia adscendens; $R$. anom.: Rinodina anomala; $R$. dalm.: Rinodina dalmatica; V. hemi.: Varicellaria hemisphaerica; X. pari.:Xanthoria parietina

Table 2 : Determined lichen taxa on Pinus brutia and their indicator values of poleotolerance $(P)$ and eutrophication tolerance $(E)$ according to Nimis and Martellos (2017)

\begin{tabular}{lll}
\hline Determined lichen taxa & PValues & EValues \\
\hline Amandinea punctata (Hoffm.) Coppins \& Scheid. & $1-2-3$ & $2-3-4$ \\
Athallia pyracea (Ach.) Arup, Frödén \& Søchti & $1-2$ & $2-3-4$ \\
Collema furfuraceum (Arnold) Du Rietz & $1-2-3$ \\
Evernia prunastri (L.) Ach. & $1-2$ & $1-2-3$ \\
Huneckia pollinii (A. Massal.) S.Y. Kondr. etal. & 1 & $2-3$ \\
Hypocenomyce scalaris (Ach.) M. Choisy & $1-2$ & 1 \\
Lecanora chlarotera Nyl. & $1-2-3$ & $2-3-4-5$ \\
Lecanora expallens Ach. & $1-2$ & $1-2$ \\
Lecidella elaeochroma(Ach.) M. Choisy & $1-2-3$ & $2-3-4$ \\
Lepra albescens (Huds.) Hafellner & $1-2$ & $1-2-3$ \\
Parmelina tiliacea(Hoffm.) Hale & $1-2-3$ & $2-3$ \\
Phaeophyscia orbicularis (Neck.) Moberg & $1-2-3$ & $4-5$ \\
Physcia adscendens (Fr.) H. Olivier & $1-2-3$ & $3-4-5$ \\
Rinodina anomala (Zahlbr.) H. Mayrhofer \& Giralt & 1 & $2-3$ \\
Rinodina dalmaticaZahlbr. & 1 & $1-2$ \\
Varicellaria hemisphaerica(Flörke) I.Schmitt \& Lumbsch & $1-2-3$ & $1-2$ \\
Xanthoria parietina(L.) Th. Fr. & $1-2-3$ & $3-4$
\end{tabular}

Abbrevations: Species indicator of P 1: natural or semi-natural habitats; P 1-2: natural or semi-natural habitats to moderately disturbed areas; $P$ 1-2-3: natural or semi-natural habitats to heavily disturbed areas; E 1: no eutrophication; E 2-3: very weak to weak eutrophication; E 3-4-5: very weak to very high eutrophication; $E$ 1-2: no to very weak eutrophication; E 1-2-3: no to weak eutrophication; E 2-3-4: very weak to rather high eutrophication; $E$ 2-3-45: very weak to very high eutrophication; E3-4: weak to rather high eutrophication; E 4-5: rather high to very high eutrophication

were unequal (Levene Statistic $p=0.000$ ), Tamhane's T2 posthoc test was applied to determine which species richness of environmental condition area differed from the others. All these analyses were performed by SPSS 23.0 .

Differences of community composition were analyzed with non-metric multidimensional scaling (NMS) (Clarke, 1993; McCune and Grace 2002) using "medium" autopilot mode with the Sørensen (Bray-Curtis) distance measurement. Autopilot mode performs 50 runs with the real dataset compared with 50 randomized runs, each run with 200 iterations. Tie handling was done by penalizing unequal ordination distance (Kruskal's secondary approach).
To reveal the relationship between determined environmental quality indicator taxa (Nimis and Martellos 2017) in the four areas and general species composition, a second NMS matrix was prepared. This matrix included distribution of species frequencies according to eutrophication tolerance (E) and poleotolerance (P) levels of Nimis and Martellos (2017). The eutrophication tolerance values, including deposition tolerance of dust and nitrogen compounds, were graded from 1 to 5 (not resistant to high resistant) by Nimis and Martellos (2017). Also poleotolerance values were graded according to human disturbance from 0 to 3 (viability of species in undisturbed areas to heavily disturbed areas). Lichen species in KWNP were classified 
according to these indicator classes. A second matrix was obtained from the frequency data of these species. Then the relation between main and second matrix was examined on a joint plot. The positive or negative correlation between the species composition and indicator variations in the second matrix appeared as vectors on the NMS graph. Direction of these vectors showed positive or negative relationship between indicator variations and community composition representing four environmental conditions. Indicator variation of lichen taxa determined from the survey areas are given in Table 2. Also by multi-response permutation procedure (MRPP) analysis (McCune and Grace 2002), community composition of four environmental condition areas were compared. Both analyses were done on PC-ORD 6.08.

Indicator Species Analysis (Dufrêne and Legendre 1997) was used to determine how strongly each specie is related to four different environmental conditions. Indicator value (IV) range from 0 to 100. Reliability of results was determined with Monte Carlo test. The analyses were performed using PC-ORD 6.08.

\section{Results and Discussion}

In this study, in total 17 taxa lichen (Table 2) were identified on $P$. brutia trees in the research area. Of all these taxa, Rinodina anomala is a new record for Turkey. This species is widely distributed in the southern Europe and Macaronesia and is also known from Dalmatia, Portugal, Spain, Sardinia, Canary Isles, Corsica, Croatia, Cazziol Island and Lagosta (Giralt and Matzer, 1994).

Comparing the four environmental conditions of the research area in terms of species richness, at least the richness of one area was found to be significantly different from the others'. (Kruskal Wallis $\mathrm{H}, p=0.000$ ). Non-parametric Tamhane's T2 posthoc test was used to determine which data of area or areas were different from the others. According to the test results, PPF were statistically different from other areas ( $p=0.000$ for each compared area) in terms of species richness. It was also one among the least amount of richness of species within the four environmental conditions (AG: 7, NNB: 9, NPF: 13, PPF: 5) (Table 1). No significant difference was noted between the other areas.

According to frequency data of survey areas, species community composition was analyzed by non-metric multidimensional scaling (NMDS). Three axes explained 49.68\%, $26.67 \%$ and $16.81 \%$ of total variation (totally $93.16 \%$ ). In addition, three dimensional solutions resulted in a final stress of 15.98 and a final instability of 0.00000 for 71 iterations. Results matches with the NMS final stress value expectation of McCune and Grace (2002) which are to be between 10 and 20 in the ecological community datasets.

In addition, relation between all species frequency of four environmental conditions and species frequency of environmental quality indicator species (species were grouped according to poleotolerance and eutrophication tolerance values of Nimis and Martellos, 2017) was examined. NMS ordinate graphs are given from two separate dimensions in Fig. 2. The joint plot vectors seen in the graphics are indicator variations that correlate. Of these variations, it was determined that indicator species data of natural or semi-natural habitats $(P 1)(r=0.538)$ and indicator species data of no to weak eutrophication (E 1-2-3) $(r=0.522)$ showed positive correlation with axis 1 (Fig. 2a, b). On the other hand, indicator species data of weak to rather high eutrophication (E 3-4) $(r=-0.462)$ showed negative correlation with this axis (Fig. 2a, b). Indicator species data of very weak to very high eutrophication (E 3-4-5) $(r=-0.464)$ showed negative correlation with axis 2 (Fig. 2a). Indicator species data of natural or semi-natural habitats to heavily disturbed areas $(P 1-2-3)(r=-$ $0.492)$ (Fig. 2b) and weak to rather high eutrophication (E 3-4) $(r=$ - 0.538) (Fig. 2a, b) showed negative correlations with axis 3 . When data of four environmental conditions was computed by convex hulls in the graphics, $P 1$ and $E$ 1-2-3 variations were related to natural pine forest area (NPF) and P 1-2-3, E 3-4, E 3-45 variations were related to other three environmental conditions data (NNB, PPF and AG).

Also in this study, the lichen community composition of four environmental conditions were compared with MRPP analysis. In MRPP analysis, in case chance-corrected withingroup agreement value $(A)$ was higher than 0.3 , this $A$ value indicated that the composition was different (McCune and Grace, 2002). Accordingly, the lichen community composition of NPF from AG's $(A=0.293, p=0.0000003)$ and the composition of NNB from NPF's $(A=0.290, p=0.0000006)$ were significantly different. Since, the $p$ value was less than 0.001 , the community composition of NPF was slightly different than PPF's $(A=0.16, p=$ $0.00006)$. In other pairwise comparison, no significant difference was observed.

Indicator species analysis (Dufrêne and Legendre 1997), revealed that Xanthoria parietina (IV $=41.0, p<0.05$; 0.0165), Amandinea punctata (IV $=38.1, p<0.01 ; 0.0037$ ) were indicator species of lichen composition of NNB; Athallia pyracea (IV = 43.1, $p<0.001 ; 0.0004)$, Lepra albescens (IV $=30.8, p<0.01 ; 0.0093$ ) and Lecanora expallens (IV $=30.8, p<0.05 ; 0.0110)$ of NPF's and Phaeophyscia orbicularis (IV = 57.7, $p<0.001 ; 0.0002$ ) of AG, respectively. No indicator species was found to be associating with the lichen community composition of PPF.

In the study area, 17 taxa lichens have been identified on P. brutia trees. This pine specie is distributed Turkey, Greece, Cyprus and Crete. Also, P. brutia are partially distributed in identified Syria, Lebanon, Italy, Iran and Iraq (Fady et al., 2003). Pirintsos and Loppi, (2003) 23 taxa of lichens were P. brutia in Kavala, Greece, when the results of the study from $172 \mathrm{~km}^{2}$ area in 3 different elevation regions of Kavala and the results obtained from the KWNP (660 ha) were compared, 0.48 similarity ratio (8 


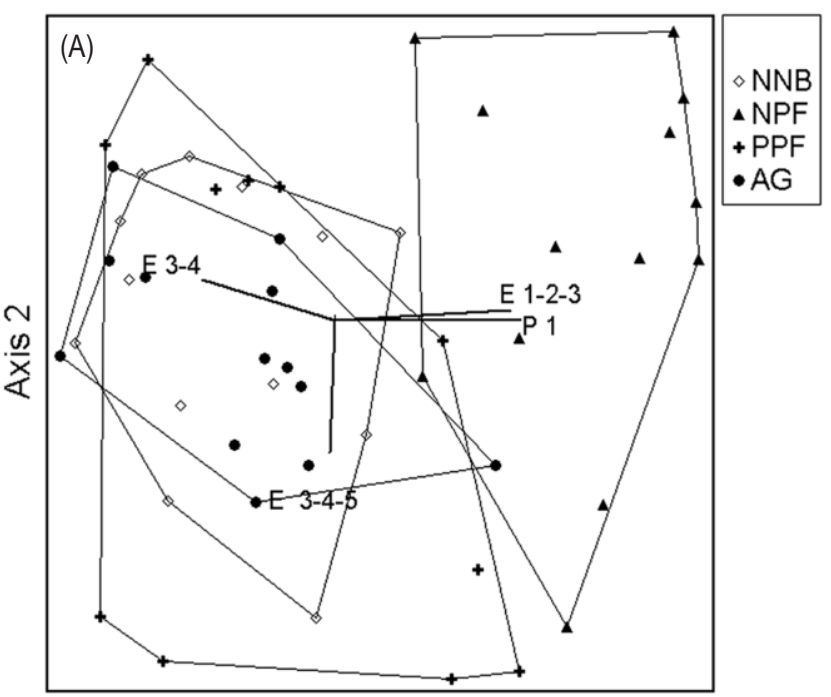

Axis 1

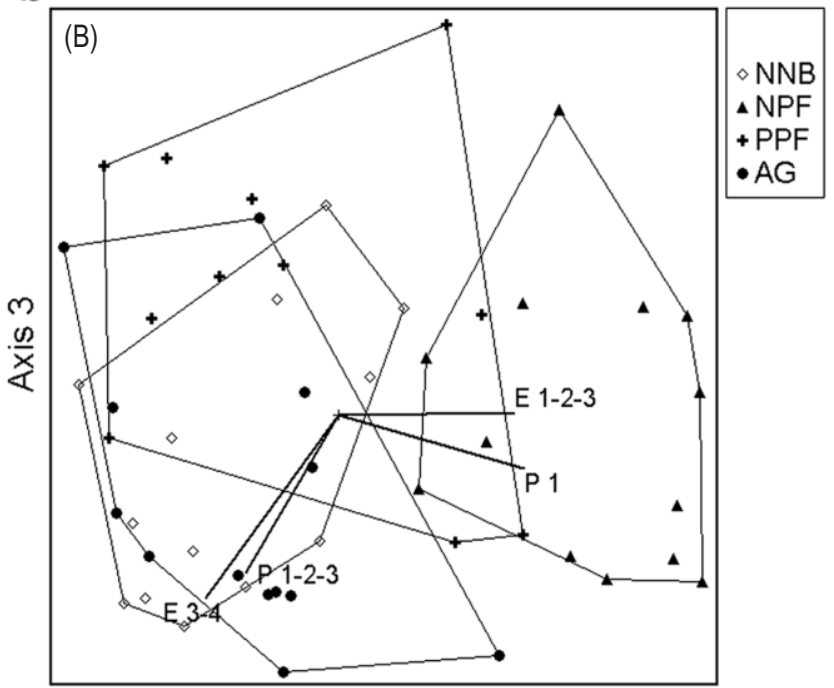

Axis 1

Fig. 2 : NMS ordinate graphs from two separate dimensions: (A) Axis 1- Axis 2 (dimension 1), (B) Axis 1- Axis 3 (dimension 2). Abbrevations: AG: Agricultural Greenhouses Area; NNB: Natural Area Near Brook; NPF: Natural Pine Forest Area; PPF: Planted Pine Forest Area; E: The eutrophication tolerance values, including the deposition tolerance of the dust and nitrogen compounds, were graded from 1 to 5 (not resistant to high resistant); $P$ : The poleotolerance values, were graded according to human disturbance from 0 to 3 (viability of species in undisturbed areas to heavily disturbed areas).

common taxa) was found according to the Sorensen similarity index. On P. brutia in Thessalonki, another city of Greece, two studies were done from sea level to $600 \mathrm{~m}$ in the region of 5800 $\mathrm{km}^{2}$ area. In one of these studies, 22 taxa were determined in 1987 (Diamantopoulos et al., 1992). In 1997, the number of taxa decreased to 12 (Vokou et al., 1999). With the results of KWNP, data of Thessalonki-1987 showed 0.26 similarity ratio ( 5 common taxa) and 1999's was 0.35 (4 common taxa). This change had been linked to human destruction and pollution in Thessaloniki (Vokou et al., 1999). P. tiliacea, which is the lost specie of Thessaloniki over the period of 10 years, is present in NPF and PPF areas in KWNP but not in AG and NNB areas. This specie is common and widely distributed in Europe (Nunez-Zapata et al., 2011) and does not exist in AG and NNB areas as these areas may have been affected by human destruction, pollution or environmental change.

In this study, KWNP was divided into four environmental conditions parts (AG: 7, NNB: 9, NPF: 13, PPF: 5) and these were compared in terms of species richness and community composition of species. According to the results, it was found that species richness of PPF was statistically different than other parts. Humphrey et al. (2002) compared the lichen species richness of planting forests and semi-natural forests in different regions of Britain. Similar to the results of KWNP, it was found that the richness of lichen species on the planted tree area was different and poor than other compared areas.

Correlation between species frequency of four environmental conditions and frequency of poleotolerance and eutrophication tolerance indicator species classified by Nimis and Martellos (2017) was examined by NMS analysis. It was found that $P 1$ and $E$ 1-2-3 variations were related with natural pine forest area (NPF) data and P 1-2-3, E 3-4, E 3-4-5 variations were related with the date of other three environmental conditions. Also when lichen community composition of four environmental conditions were compared with MRPP analysis, it was found that the lichen community composition of NPF were significantly different than AG's and NNB's, and slightly different than PPF's. According to these results, it can be said that the natural pine forest area (NPF) has quality of natural or semi-natural habitat. Also no or less eutrophication occurs in this area. In other areas, due to the presence of community composition with wide ecological tolerance in terms of human destruction and eutrophication (according to NMS results), it is possible to conclude that these areas are affected by the existing human damage and eutrophic load in the surroundings. Pinho et al. (2009) reported that with increase in eutrophication, the richness and abundance of nitrophytic species increases and oligotrophic species decrease. In the study, from eutrophication tolerance data of Nimis and Martellos (2017), 1 and 2 were defined as oligotrophic; and 4 and 5 were classified as eutrophic. In another study where these classifications were used, a significantly higher correlation was found between the distribution of lichens and ammonia pollution $\left(\mathrm{NH}_{3}\right)_{\text {atm }}$ that caused the lichen community to change from oligotrophic to nitrophytic (Pinho et al., 2011). According to Munzi et al. (2014), oligotrophic lichen species are negatively affected with the increase in ammonia concentration. As ammonia causes loss of biodiversity in terrestrial ecosystems 
(Asman et al., 1998; Krupa 2003; Erisman et al., 2007; Sutton et al., 2008; Clarisse et al., 2009), it is used for classifying air quality (Lelieveld et al., 2015). According to Jovan et al. (2012), increase in nitrophytic lichen species are highly correlated not only with increase in ammonia content, but also with increase in different forms of nitrogen.In Europe and Turkey, agricultural activities are the main source of pollution (Lelieveld et al., 2015) and agricultural activity is considered to be the main source of ammonia $\left(\mathrm{NH}_{3}\right)$ and $\mathrm{NO}_{\mathbf{x}}$ pollutants (van Aardenne et al., 2001; Barman et al., 2010; Jiang et al., 2016). Accordingly in the KWNP, since community composition of the region from NPF to other areas changed from oligotrophic to nitrophytic, it can be concluded that the NNB, PPF and AG areas are under the influence of agricultural pollution (Fig. 2).

In addition, NNB, defined as a natural part of research area, had a different community composition than NPF whereas it was not different from AG, so this indicates that NNB may be affected by pollution. This may be explained as the brook in the area may carry the agricultural pollution load from $A G$ and other surrounding regions to NNB, also altering the lichen composition of NNB. Şener et al. (2017) investigated the water quality of Aksu River and reported the area including Aksu River flow through KWNP is one of the areas that has highest amount of $\mathrm{NO}_{2}$ and $\mathrm{NO}_{3}$ that cause eutrophic pollution. Also, high amount of $\mathrm{NH}_{3}, \mathrm{NO}_{2}$ and $\mathrm{O}_{3}$ is formed in greenhouses where $\mathrm{N}$-fertilization is applied (Jiang et al., 2016). Since these substances are mostly spread by water and air from open system greenhouses in AG, they may be a significant cause of eutrophication in the park.

According to indicator species analysis, it was found that $X$. parietina and $A$. punctata indicated the lichen community composition of NNB. X. parietina is a nitrophytic species (Ruoss, 1999; Van Herk, 2001; Munzi et al., 2014) and its presence decreases in non-nitrogen-rich ecosystems (Van Herk, 1999; Munzi et al., 2014). Another nitrophytic species, A. punctata (Hauck, 2010) prefers organic and inorganic salts (Hafellner and Casares-Porcel, 2003) and, therefore, is resistant to air pollution and inorganic fertilizers (Smith et al., 2009). These species indicate that NNB has undergone environmental change due to pollution. In addition, it was determined that the lichen community composition of $A G$ is strongly related to $P$. orbicularis. This specie is extremely tolerance to nitrogen and dust (Ellenberg et al., 1992; Van Herk, 1999; Stapper and Kricke, 2004; Larsen et al., 2007), shows positive correlation with high amount of $\mathrm{NO}_{x}$ in terms of frequency and number of individuals (Larsen et al., 2007). Furthermore, $P$. orbicularis has the highest eutrophication tolerance (according to Nimis and Martellos indicator values (E 45)) among all species identified in the park. Although, there is no statistical difference in the lichen community composition of $A G$ and NNB, it can be said that AG is most pollution exposed area within the four environmental condition areas.
A. pyracea, $L$. albescens and $L$. expallens species were related to NPF's lichen composition. According to poleotolerance evaluation of Nimis and Martellos (2017), these three species belong to habitats varying from natural or semi-natural to moderately disturbed (P 1-2). Except for these three, all indicator species of other areas are ecologically tolerant to habitats varying from natural or semi-natural to heavily disturbed (P 1-2-3). Moreover, presence of L. albescens (Loppi, 2000; Nimis and Martellos, 2017) and L. expallens (Nimis and Martellos, 2017) are non-nitrophytic species less exposed to pollution. However, $A$. pyracea, one of the member of nitrophytic communities (Vondrak et al., 2016), is an epiphytic specie found on deciduous trees, eutrophic wood pieces or lime-impregnated Pinus and Juniperus (Arup, 2009). According to Nimis and Martellos (2017), this specie can be found between less and more eutrophic ecosystems (E 23-4). The rapy implying that NPF is slightly affected by pollution.

According to Antón et al. (2007), lands use for agriculture changes biodiversity, equal to or slightly less than those used for urban. With increase in non-ecological agriculture, environmental changes occur in a city. Although KWNP is surrounded by greenhouses where non-ecological agriculture is practised and simultaneously its natural habitat is being preserved. The results obtained from lichens indicate that some parts of park have not lost their natural structure, but some parts were heavily exposed to agricultural pollution. In this study, one more time it has been proved that epiphytic lichens change their community composition by adapting to environmental changes. This study also showed that lichen species are strong indicators of environmental change.

\section{References}

Antón, A., F. Castells and J.I. Montero: Land use indicators in life cycle assessment. Case study: The environmental impact of Mediterranean greenhouses. J. Clean. Prod., 15, 432-438 (2007).

Arup, U. : The Caloplaca holocarpa group in the Nordic countries, except Iceland. Lichenologist, 41, 111-130(2009).

Asman, W.A., M.A. Sutton and J.K. Schjørring: Ammonia: Emission, atmospheric transport and deposition. New Phytol., 139, 27-48, (1998).

Asta, J., W. Erhardt, M. Ferretti, F. Fornasier, U. Kirschbaum, P.L. Nimis, O.W. Purvis, S. Pirintsos, C. Scheidegger, C. Van Haluwyn and V. Wirth: Mapping lichen diversity as an indicator of environmental quality. In: Monitoring with Lichens - Monitoring Lichens (Eds.: P.L. Nimis, C. Scheidegger and P.A. Wolseley) Springer, Dordrecht, pp. 273-279 (2002a).

Asta, J., W. Erhardt, M. Ferretti, F. Fornasier, U. Kirschbaum, P.L. Nimis, O.W. Purvis, S. Pirintsos, C. Scheidegger, C. Van Haluwyn and V. Wirth: European guideline for mapping lichen diversity as an indicator of environmental stress. The British Lichen Society. Kluwer Academic Publishers, Dordrecht, Boston, London, (2002b).

Barman, S.C., N. Kumar, R. Singh, G.C. Kisku, A.H. Khan, M.M. Kidwai, R.C. Murthy, M.P.S. Negi, P. Pandey, A.K. Verma, G. Jain and S.K. Bhargava: Assessment of urban air pollution and it's probable health impact. J. Environ. Biol., 31, 913-920 (2010). 
Bergamini, A., C. Scheidegger, S. Stofer, P. Carvalho, S. Davey, M. Dietrich, F. Dubs, E. Farkas, U. Groner, K. Kärkkäinen, C. Keller, L. Lökös, S. Lommi, C. Máguas, R. Mitchell, P. Pinho, V.J. Rico, G. Aragón, A.M. Truscott, P.A. Wolseley and A. Watt: Performance of macrolichens and lichen genera as indicators of lichen species richness and composition. Conserv. Biol., 19, 1051-1062 (2005).

Clarisse, L., C. Clerbaux, F. Dentener, D. Hurtmans and P.F. Coheur: Global ammonia distribution derived from infrared satellite observations. Nat. Geosci., 2, p. 479 (2009).

Clarke, K.R.: Non-parametric multivariate analyses of changes in community structure. Aust. J. Ecol., 18, 117-143 (1993).

Cristofolini, F., P. Giordani, E. Gottardini and P. Modenesi: The response of epiphytic lichens to air pollution and subsets of ecological predictors: A case study from the Italian Prealps. Environ. Pollut. 151, 308-317 (2008).

Diamantopoulos, J., S. Pirintsos, J.R. Laundon and D. Vokou: The epiphytic lichens around Thessaloniki (Greece) as indicators of sulphur dioxide pollution. Lichenologist, 24, 63-71 (1992).

Dufrêne, M. and P. Legendre: Species assemblages and indicator species: The need for a flexible asymmetrical approach. Ecol. Monograph., 67, 345-366 (1997).

Ellenberg, H., R. Düll, V. Wirth, W. Werner and D. Paulissen: Zeigerwerte von Pflanzen in Mitteleuropa. Scr. Geobot., 18, 215-237 (1992).

Erisman, J.W., A. Bleeker, J. Galloway and M.S. Sutton: Reduced nitrogen in ecology and the environment. Environ. Pollut., 150, 140-149 (2007)

Fady, B., H. Semerci and G.G. Vendramin: EUFORGEN Technical Guidelines for genetic conservation and use for Aleppo pine (Pinus halepensis) and brutia pine (Pinus brutia). International Plants Genetic Resources Institute. Rome, Italy (2003).

Frati, L., S. Santoni, V. Nicolardi, C. Gaggi, G. Brunialti, A. Guttova, S. Gaudino, A. Pati, S.A. Pirintsos and S. Loppi: Lichen biomonitoring of ammonia emission and nitrogen deposition around a pig stockfarm. Environ. Pollut., 146, 311-316 (2007).

Giordani, P.: Variables influencing the distribution of epiphytic lichens in heterogeneous areas: A case study for Liguria, NW Italy. J. Veg. Sci., 17, 195-206 (2006).

Giralt, M.: The lichen genera Rinodina und Rinodinella (lichenized Ascomycetes, Physciaceae) in the Iberian Peninsula. Biblioth. Lichenol., 79, 1-160 (2001).

Giralt, M. and M. Matzer: The corticolous species of the genus Rinodina with biatorine or lecideine apothecia in southern Europe and Macaronesia. Lichenologist, 26, 319-332 (1994).

Gombert, S., J. Asta and M.R.D. Seaward: Correlation between the nitrogen concentration of two epiphytic lichens and the traffic density in an urban area. Environ. Pollut., 123, 281-290 (2003).

Hafellner, J. and M. Casares-Porcel: Lichenicolous fungi invading lichens on gypsum soils in southern Spain. Herzogia, 16, 123-133 (2003).

Hauck, M. : Ammonium and nitrate tolerance in lichens. Environ. Pollut. $158,1127-1133(2010)$.

Hawksworth, D.L. and F. Rose: Qualitative scale for estimating sulphur dioxide air pollution in England and Wales using epiphytic lichens. Nature, 227, 145-148(1970).

Humphrey, J.W., S. Davey, A.J. Peace, R. Ferris and K. Harding: Lichens and bryophyte communities of planted and semi-natural forests in Britain: The influence of site type, stand structure and deadwood. Biol. Cons., 107, 165-180 (2002).

Jiang, Z., Q. Zeng, H. Pi and B. Tie: Variation in characteristics of air concentrations of $\mathrm{NH}_{3}, \mathrm{NO}_{2}$ and $\mathrm{O}_{3}$ induced by applications of urea in soils of plastic greenhouses in suburban China. Atmos. Pollut. Res., 7, 619-625 (2016).

Johansson, P. and J. Ehrlén: Influence of habitat quantity, quality and isolation on the distribution and abundance of two epiphytic lichens. J. Ecol., 91, 213-221 (2003).

Jovan, S.: Lichen bioindication of biodiversity, air quality and climate: Baseline results from monitoring in Washington, Oregon and California. Vol. 737, Portland, OR: US Department of Agriculture, Forest Service, Pacific Northwest Research Station (2008).

Jovan, S., J. Riddell, P.E. Padgett and T.H. Nash: Eutrophic lichens respond to multiple forms of $\mathrm{N}$ : Implications for critical levels and critical loads research. Ecol. Appl., 22, 1910-1922 (2012).

Käffer, M.I., S.M. de Azevedo Martins, C. Alves, V.C. Pereira, J. Fachel and V.M.F. Vargas: Corticolous lichens as environmental indicators in urban areas in southern Brazil. Ecol. Indic., 11, 13191332 (2011).

Krupa, S.V.: Effects of atmospheric ammonia $\left(\mathrm{NH}_{3}\right)$ on terrestrial vegetation:Areview. Environ. Pollut., 124, 179-221 (2003).

Kruskal, W.H. and W.A. Wallis: Use of ranks in one criterion variance analysis. J. Am. Stat. Assoc., 47, 583-621 (1952).

Larsen, R.S., J.N.B. Bell, P.W. James, P.J. Chimonides, F.J. Rumsey, A. Tremper and O.W. Purvis: Lichen and bryophyte distribution on oak in London in relation to air pollution and bark acidity. Environ. Pollut., 146, 332-340 (2007).

Lelieveld, J., J.S. Evans, M. Fnais, D. Giannadaki and A. Pozzer: The contribution of outdoor air pollution sources to premature mortality on a global scale. Nature, 525, 367-371 (2015).

Llop, E., P. Pinho, P. Matos, M.J. Pereira and C. Branquinho: The use of lichen functional groups as indicators of air quality in a Mediterranean urban environment. Ecol. Indic., 13, 215-221 (2012).

Loppi, S. and A.P. Stergios: Effect of dust on epiphytic lichen vegetation in the Mediterranean area (Italy and Greece). Isr. J. Plant Sci., 48 91-95 (2000)

McCune, B.: Lichen communities as indicators of forest health. Bryologist, 103, 353-356 (2000).

McCune, B.: Key to the lichen genera of the Pasific Northwest. Department of Botany and Plant Pathology, Oregon State University. Corvallis Oregon (2006).

McCune, B. and J.B. Grace: Analysis of Ecological Communities. MjM Software Design, Glenden Beach, Oregon (2002).

Munzi, S., C. Cruz, C. Branquinho, P. Pinho, I.D. Leith and L.J. Sheppard: Can ammonia tolerance amongst lichen functional groups be explained by physiological responses? Environ. Pollut., 187, 206209 (2014)

Nash, T.H.: Lichen biology. $2^{\text {nd }}$ Edn., Cambridge University Press, Cambridge, UK (2008)

Nimis, P.L. and S. Martellos: ITALIC - The Information System on Italian Lichens. Version 5.0. University of Trieste, Department of Biology, (http://dryades.units.it/italic) (2017).

Nimis, P.L., C. Scheidegger and P.A. Wolseley: Monitoring with lichensmonitoring lichens. In: Monitoring with Lichens, Springer, Dordrecht (Eds.: P.L. Nimis, C. Scheidegger and P.A. Wolseley) pp. 1-4 (2002)

Nunez-Zapata, J., P.K. Divakar, D.P. Ruth, P. Cubas, D.L. Hawksworth and A. Crespo: Conundrums in species concepts: The discovery of a new cryptic species segregated from Parmelina tiliacea (Ascomycota: Parmeliaceae). Lichenologist, 43, 603-616 (2011). 
Paoli, L., S. Munzi, A. Guttová, D. Senko, G. Sardella and S. Loppi: Lichens as suitable indicators of the biological effects of atmospheric pollutants around a municipal solid waste incinerator (S Italy). Ecol. Indic., 52, 362-370 (2015).

Pinho, P., A. Bergamini, P. Carvalho, C. Branquinho, S. Stofer, C. Scheidegger and C. Maguas: Lichen functional groups as ecological indicators of the effects of land-use in Mediterranean ecosystems. Ecol. Indic., 15, 36-42 (2012).

Pinho, P., C. Branquinho, C. Cruz, Y.S. Tang, T. Dias, A.P. Rosa, C. Máguas, M.A. Martins-Loução and M.A. Sutton: Assessment of Critical Levels of Atmospheric Ammonia for Lichen Diversity in Cork-Oak Woodland, Portugal. In: Atmospheric Ammonia (Eds.: M. Sutton, S. Reis and S.M.H. Baker), Springer, Switzerland, pp. 109-119(2009).

Pinho, P., T. Dias, C. Cruz, Y.S. Tang, M.A. Sutton M-A. Martins Loução, C. Máguas and $C$. Branquinho: Using lichen functional diversity to assess the effects of atmospheric ammonia in Mediterranean woodlands. J. Appl. Ecol., 48, 1107-1116 (2011).

Pinokiyo, A., K.P. Singh and J.S. Singh: Diversity and distribution of lichens in relation to altitude within a protected biodiversity hot spot, north-east India. Lichenologist, 40, 47-62 (2008).

Pirintsos, S.A. and S. Loppi: Lichens as bioindicators of environmental quality in dry Mediterranean areas: A case study from northern Greece. Isr. J. Plant Sci., 51, 143-151 (2003).

Ruoss, E : How agriculture affects lichen vegetation in central Switzerland. Lichenologist, 31, 63-73 (1999).

Sarıbaşak, H., S. Başaran, C. Güngöroğlu and A. Serttaş: A review report of Kurşunlu Waterfall Nature Park. Turkey, 1, (2007).

Seaward, M.R.D.: The use of lichens for environmental impact assessment. Symbiosis, 37, 293-305 (2004).

Şener, Ş., E. Şener and A. Davraz: Evaluation of water quality using water quality index (WQI) method and GIS in Aksu River (SWTurkey). Sci. Total. Environ., 584, 131-144 (2017).

Smith, C., L. Geiser, L. Gough, B. McCune, B. Ryan and R. Showman: Species and Communities. In: Lichens as Bioindicators of Air Quality (Eds.: K. Stolte, D. Mangis, R. Doty, K. Tonnessen and L.S.
Huckaby). General Technical Report RM-224. U.S. Department of Agriculture Forest Service, Rocky Mountain Research Station, Fort Collins, CO., pp. 41-66 (1993).

Smith, C.W., A. Aptroot, B.J. Coppins, A. Fletcher, O.L. Gilbert, P.W. James and P.A. Wolseley: The lichens of Great Britain and Ireland. British Lichen Society, London (2009).

Stapper, N.J. and R. Kricke: Epiphytische moose und flechten als bioindikatoren von städtischer überwärmung, standorteutrophierung und verkehrsbedingten immissionen. Limprichtia, 24, 187-208 (2004).

Sutton, M.A., J.W. Erisman, F. Dentener and D. Möller: Ammonia in the environment: From ancient times to the present. Environ. Pollut. 156, 583-604 (2008).

Van Aardenne, J.A., F.J. Dentener, G.J. Oliver, C.G.M. Klein Goldewijk and J. Lelieveld : $A 1 \times 1$ resolution data set of historical anthropogenic trace gas emissions for the period 1890-1990. Global. Biogeochem. Cycles, 15, 909-928 (2001).

Van Herk, C.M.: Mapping of ammonia pollution with epiphytic lichens in the Netherlands. Lichenologist, 31, 9-20 (1999).

Van Herk, C.M.: Bark pH and susceptibility to toxic air pollutants as independent causes of change in epiphytic lichen composition in space and time. Lichenologist, 33, 419-441 (2001).

Vokou, D., S.A. Pirintsos and S. Loppi: Lichens as bioindicators of temporal variations in air quality around Thessaloniki, Northern Greece. Ecol. Res., 14, 89-96 (1999).

Vondrák, J., M.G. Halici, M. Güllü and R. Demirel: Taxonomy of the genus Athallia and its diversity in Turkey. Turk. J. Bot., 40, 319-328 (2016).

Will-Wolf, S., S. Jovan, P. Neitlich, J.E. Peck and R. Rosentreter: Lichenbased indices to quantify responses to climate and air pollution across northeastern USA. Bryologist, 118, 59-82 (2015).

Wirth, V.: Die Flechten Baden-Württembergs Teil: 1 \& 2, Eugen Ulmer $\mathrm{GmbH}$ and Co. Stuttgart (1995).

Zarabska-Bożejewicz, D. and K. Kujawa: The effect of land use on taxonomical and functional diversity of lichens in an agricultural landscape. Fungal Ecol., 33, $72-79$ (2018). 